Bennett, J. L., E. G. Jamieson, R. A. Ronconi, and S. N. P. Wong. 2017. Variability in egg size and population declines of Herring Gulls in relation to fisheries and climate conditions. Avian Conservation and Ecology 12(2):16. https://doi.org/10.5751/ACE-01118-120216

Copyright (C) 2017 by the author(s). Published here under license by the Resilience Alliance.

Research Paper

\title{
Variability in egg size and population declines of Herring Gulls in relation to fisheries and climate conditions
}

\author{
Jessica L. Bennett ${ }^{1}$, Ellen G. Jamieson ${ }^{2,3}$, Robert A. Ronconi ${ }^{2,4}$ and Sarah N. P. Wong ${ }^{2,5}$ \\ ${ }^{1}$ Department of Civil and Resource Engineering, Dalhousie University, Halifax, NS, Canada, ${ }^{2}$ Department of Biology, Dalhousie \\ University, Halifax, NS, Canada, ${ }^{3}$ Department of Environmental and Life Sciences, Trent University, Peterborough, ON, Canada, \\ ${ }^{4}$ Canadian Wildlife Service, Environment and Climate Change Canada, Dartmouth, NS, Canada, ${ }^{5}$ Department of Biology, Acadia \\ University, Wolfville, NS, Canada
}

\begin{abstract}
Changes in clutch and egg size in many avian species have been linked to seasonal variation, female physiological state, and laying date during breeding season. These reproductive variables have also been linked to population status and habitat variables. Recent declines in Herring Gull (Larus argentatus) populations in the Atlantic region may be associated with environmental changes, fishery activities, or natural species interactions and fluctuations. We studied variability and trends in Herring Gull egg, clutch, and population size at a cluster of three islands of the Grand Manan Archipelago in the Bay of Fundy, Canada. A generalized linear model investigating variability in Herring Gull egg volume over a 28-year period (1988 to 2015) showed increasing egg volume since a low in 2000, significant positive correlations with regional fisheries landings, and weak interactions with sea surface temperature and the winter North Atlantic Oscillation (NAO) index. Herring Gull egg size decreased by $11.6 \%$ from 1988 to 2000 , but both egg size and clutch size have increased significantly since 2001. A 2015/2016 population estimate of the three islands showed a $36 \%$ decline in Herring Gull numbers since 2001. Changes in annual and seasonal availability of various fishery related food sources, specifically decreasing Atlantic herring (Clupea harengus) and groundfish landings and increasing American lobster (Homarus americanus) landings, may be linked to these increases in reproductive variables. However, it appears that other factors may be influencing the declining gull population because despite increased availability of alternative food sources and increased clutch size and egg volume, there has been no documented increase in abundance. Interspecific interactions, anthropogenic activities, and climatic variability may also have a role in these population dynamics.
\end{abstract}

\section{Variabilité de la taille des oeufs et baisse des populations chez le Goéland argenté en relation avec la pêche commerciale et les conditions climatiques}

RÉSUMÉ. Les changements dans la taille des oeufs et de la ponte chez plusieurs espèces d'oiseaux ont été associés aux variations saisonnières, à l'état physiologique des femelles et à la date de ponte pendant la saison de nidification. Des diminutions récentes des populations de Goélands argentés (Larus argentatus) dans la région de l'Atlantique seraient peut-être liées à des changements environnementaux, aux activités de pêche ou aux interactions et fluctuations naturelles des espèces. Nous avons étudié la variabilité et la tendance de la taille des oeufs, de la ponte et des populations dans un groupe de trois îles dans l'archipel de Grand Manan dans la baie de Fundy, Canada. Un modèle linéaire généralisé conçu pour examiner la variabilité du volume des oeufs de ce goéland sur une période de 28 ans (1988 à 2015) a révélé un volume croissant depuis un minimum atteint en 2000, une corrélation positive significative avec les débarquements de pêche commerciale régionale et de faibles interactions avec la température de surface de la mer et l'indice d'oscillation nord-atlantique en hiver. La taille des oeufs a diminué de 11,6\% de 1988 à 2000, mais celle-ci et la taille de la ponte ont toutes deux augmenté significativement depuis 2001. Le décompte des Goélands argentés sur les trois îles en 2015-2016 a permis de constater qu'il s'est produit une baisse des effectifs de $36 \%$ depuis 2001 . Les changements dans la disponibilité annuelle et saisonnière des diverses ressources alimentaires liées à la pêche commerciale, particulièrement la diminution des débarquements de Harengs de l'Atlantique (Clupea harengus) et de poissons de fond et l'augmentation des débarquements de homards (Homarus americanus), pourraient être liés à ces hausses de paramètres de reproduction. Toutefois, il semble que d'autres facteurs influent peut-être sur la diminution des effectifs de goélands parce qu'en dépit de la hausse de la disponibilité d'autres ressources alimentaires et de l'augmentation de la taille de la ponte et du volume des oeufs, aucune hausse des effectifs n'a été observée. Les interactions interspécifiques, les activités d'origine anthropique et la variabilité du climat pourraient aussi jouer un rôle dans ces dynamiques de population.

Key Words: clutch size; egg volume; fishery subsidies; Laridae; North Atlantic Oscillation index; population declines; sea surface temperature

Address of Correspondent: Ellen G. Jamieson, Department of Biology, Dalhousie University, 1355 Oxford St., Halifax, NS, Canada,

ellenjamieson@trentu.ca 


\section{INTRODUCTION}

Seabirds and coastal avian species can be used as indicators of environmental health and variation (Furness and Camphuysen 1997, Mallory et al. 2010) by revealing changes in ecosystem quality (Gremillet and Boulinier 2009) and productivity (Barber and Chavez 1983, Cairns 1987), and can thereby indicate pressures on natural resources and priorities for conservational efforts. Changes in habitat variables have been correlated with a decline in reproductive success (Hipfner 2012), fledging recruitment (Wanless et al. 2005), clutch size (Clifford and Anderson 2001), and egg size in marine birds (Blight 2011, Barrett et al. 2012). Ultimately, these measures of productivity and reproductive success are linked to individual survival and overall population trends.

Measures of reproductive success, clutch size, and egg size can be variable from year to year, often affected by multiple environmental and biological factors (Parsons 1975, Coulson et al. 1982, MacInnes and Dunn 1988). Herring Gulls (Larus argentatus) typically lay between one and three eggs with selective pressure for a maximum clutch size of three (Niizuma et al. 2005). Therefore, changes in Herring Gull clutch size may be linked to fluctuations in habitat and climatic variables rather than intrinsic interannual variability. For example, food availability may affect female physiological state in Herring Gulls which, in turn, can affect date of egg laying, and consequently, clutch size (Parsons 1975). Egg size may also vary with physiological state and date of laying, whereby birds breeding in optimal conditions will often lay larger eggs (Coulson et al. 1982), and those that lay later in the season may have smaller eggs (Parsons 1975).

In addition to affecting clutch and egg size, variation in food availability often leads to changes in nestling growth and productivity (Abraham and Sydeman 2004, Piatt et al. 2007). In cases where prey abundance and density are consequences of environmental disturbances such as large-scale depletion of forage fish stocks, breeding success and other life history traits may be negatively affected (Cairns 1987, Cury et al. 2011). Quantification of seabird life history parameters, in conjunction with census data, helps to monitor the relationship between colony size, density, and breeding biology (Coulson et al. 1982).

In recent decades, there have been declines in Herring Gull populations throughout much of the North Atlantic region (Anderson et al. 2016). Proposed factors implicated with these population changes range from anthropogenic activities, such as waste management (Pons 1992), and interactions with commercial fisheries (Boyne and Beukens 2004, Wilhelm et al. 2016), to natural evolutionary trajectories due to predation and interspecific interactions (MacKinnon and Kennedy 2014). Thus, it is difficult to pinpoint the underlying mechanism of these population changes.

Kent, Sheep, and Hay islands, located in the Grand Manan archipelago off the coast of New Brunswick, Canada (Fig. 1), are important habitats and breeding grounds for a variety of bird species. Kent Island is an especially important breeding colony for Herring Gulls because it has been among the largest colonies for this species in eastern Canada since the 1940s (Ronconi and Wong 2003). In the last several decades, Herring Gulls nesting in the Bay of Fundy have shown large fluctuations in population size (Pierotti and Good 1994, Ronconi and Wong 2003). This population has not been surveyed since 2001, and therefore, a
Fig. 1. Study area with inset map showing study colonies. Star indicates location of study colonies relative to Grand Manan Island. Areas for which regional fisheries landings data were acquired include Lobster Fishing Area (LFA) 35-38 (DFO 2013a) and, for herring, the Southwestern Nova Scotia and Bay of Fundy portion of zone $4 \mathrm{X}$ delineated by dark lines (DFO 2016). Inset shows surveyed areas for nesting gulls and eiders on Kent, Sheep, and Hay Islands (adapted from Ronconi and Wong 2001), except for the forested areas, which were not surveyed. On Kent Island, direct nest counts were performed for sections A (6.33 ha), C (4.90 ha), D ( 2.31 ha; NW shoreline and basin), and E ( 1.21 ha; NE shoreline). Transect surveys were conducted in section B (31.79ha). Direct counts were conducted throughout Sheep and Hay Islands.

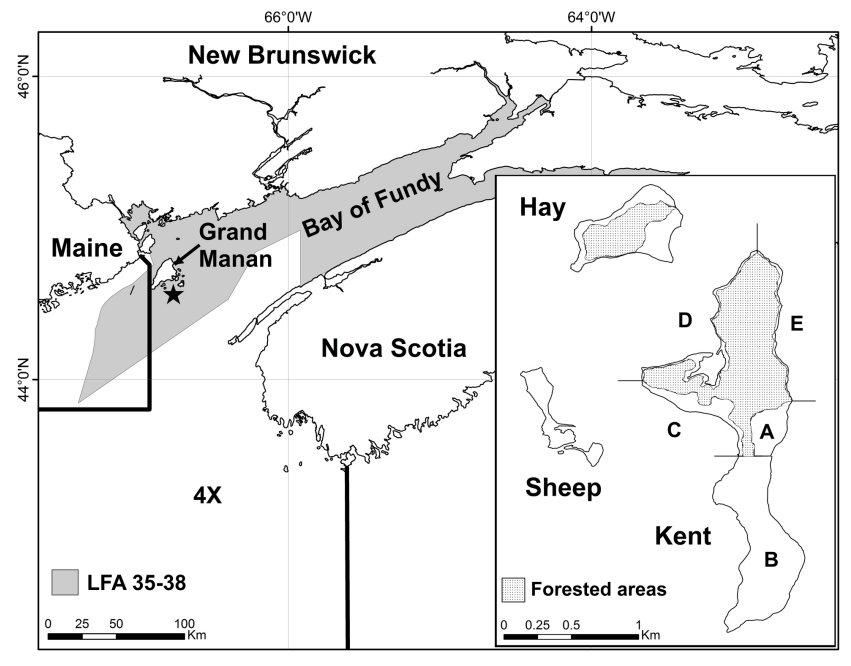

follow-up survey of the Kent, Sheep, and Hay Island colonies will assess the current status of the population.

Our objectives were to investigate the variability and changes in egg, clutch, and population size for Herring Gulls nesting in the lower Bay of Fundy. Based on recent environmental and ecological changes in this region, and in light of declining populations observed elsewhere along the Atlantic coast of North America (Anderson et al. 2016), we expected to see declines in population size of Herring Gulls nesting on the three islands. Considering that egg production in gulls may be sensitive to longterm changes in environmental conditions or food availability (Blight 2011) and that the diet of gulls from Kent Island is primarily of marine sources (Steenweg et al. 2011), we used archived Herring Gull egg measurements (from 1988 to present) and a modeling approach to examine whether changes in ocean climate and fisheries related prey availability may be contributing to demographic changes observed on Kent Island. Specifically, we examined correlations between egg volume and three environmental variables. First, because Herring Gull diets at this colony include a large proportion of fish (Steenweg et al. 2011) and this species is frequently observed scavenging around fishing vessels, we examined correlations between egg volume and regional and local landings of herring, lobster, and groundfish. Second, because the winter North Atlantic Oscillation (NAO) index has been shown to affect zooplankton abundance in the 
nearby Gulf of Maine (Conversi et al. 2001), the NAO can be used as a measure of broad-scale climatic and environmental conditions for our study area (Hurrell and Deser 2009). Finally, local climatic variables, such as sea surface temperature (SST), may also affect the prey base for seabirds and impact egg laying (e.g., Barrett et al. 2012). We predicted positive correlations between Herring Gull egg volume and fisheries landings, but we had no a priori expectations on the direction or magnitude of SST or NAO effects. Overall, we expected to see declining population estimates, in keeping with regional trends (Anderson et al. 2016) that may be associated with declines in egg production including lower clutch size and egg volume.

\section{METHODS}

Fieldwork was conducted during early June of 2015 and 2016 on three islands of the Grand Manan archipelago in the Bay of Fundy, Canada: Kent Island (44 $\left.58^{\prime} 19 \mathrm{~N}, 66^{\circ} 75^{\prime} 58 \mathrm{~W}\right)$, Hay Island

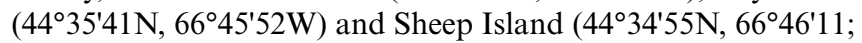
Fig. 1). The three islands are separated by less than $1 \mathrm{~km}$ of water and are connected to each other on very low tides. Among the three islands, a census in 2001 estimated colony size of approximately 7000 breeding pairs of Herring Gull (Ronconi and Wong 2003).

\section{Egg volume}

Fifteen Herring Gull nests on Kent Island were selected haphazardly, during the census (below), to measure egg size. The length and width of each egg in a nest was measured with dial calipers $(0.1 \mathrm{~mm}$ precision) and used to calculate volumetric measures for each egg. Egg volume was calculated following Harris (1964): $V=l \times w^{2} \times k / 1000$ where $V=$ volume $\left(\mathrm{mm}^{3}\right), l$ $=$ length $(\mathrm{mm}), w=$ width $(\mathrm{mm}), k=$ constant of 0.476 . Additional egg measurements from Kent Island were obtained from 11 years between 1988 and 2014 from archived data of the Environment and Climate Change Canada toxicological egg sampling program (Burgess et al. 2013), where 15 eggs were measured every four years from 1988 to 2008 and then annually from 2010 for a total sample size of 170 eggs. These archived data included only one egg sampled randomly from each nest. Egg measurements in 2015 were from nests throughout the island, but locations of previous egg sampling were unknown.

\section{Prey and environmental covariates}

Averaged SST in the top $5 \mathrm{~m}$ of the water column for the month of May was obtained from monthly conductivity-temperaturedepth (CTD) casts conducted at the Prince 5 station $\left(44.93^{\circ} \mathrm{N}\right.$ $66.85^{\circ} \mathrm{W}$ ) in the lower Bay of Fundy (DFO 2013b). Principalcomponent based NAO indices averaged over winter (December/ January/February) were obtained from the National Center for Atmospheric Research (NCAR 2015); winter NAO is predictive of baseline biological productivity in this region (Conversi et al. 2001).

We used the following variables as indices of prey availability: Atlantic herring (Clupea harengus) landings, American lobster (Homarus americanus) landings, and Atlantic groundfish landings. Herring landings were considered indices of the abundance of "natural" prey in the Bay of Fundy though gulls may also take herring during fishing operations, whereas lobster and groundfish landings represent an index of anthropogenic food subsidies to gulls because both fisheries offer food from discards of bait and/or offal. Herring landings for region 4VWX were obtained from the Department of Fisheries and Oceans reports (DFO 2016) and includes summer, fall, and winter purse seine, herring weir and shutoffs; for this study we used only the landings from Bay of Fundy and Southwest Nova Scotia portions of region $4 \mathrm{X}$ (Fig. 1), which comprise approximately $80 \%$ of the 4VWX landings. Yearly lobster landings for the Lobster Fishing Areas (LFA) around the Grand Manan Archipelago (LFA 35-38) were obtained from published reports (DFO 2013a, DFO 2015). Groundfish landings for the local study area were not available over the period of interest, therefore, we used groundfish landings (cod, hakes, and haddocks) for the Canadian section of the Northwest Atlantic as per Farmer and Leonard (2011) and data obtained from the Food and Agriculture Organization of the United Nations (FAO 2016).

Individual fisheries datasets were used in separate models (see list of candidate models below), but the direct use of landings data as predictors of egg size could not be combined in a single model for three reasons. First, the available landings data from the three fisheries are not directly comparable because they are reported at different spatial scales, e.g., local landings for lobster, regional landings of herring, and national statistics for groundfish, thus, representing landings of different orders of magnitude (Fig. 2). Second, the biomass of food available to gulls in relation to landings is unknown and is likely to differ among fisheries. Finally, because gulls are likely reliant on all three fisheries, some index of total fisheries landings is likely to reflect food availability better than each fishery included separately in one model. Therefore, to calculate a simplified metric of relative food availability from the three fisheries, we developed a "fishery index" using a combination of the herring, lobster, and groundfish landings. For each of the three fisheries, an index was calculated as follows: landings for year $\mathrm{X}$ divided by the maximum landings for the period of 1988-2014, where 0 would be no landings and 1 would be the maximum annual landings for that time period. The cumulative fishery index was calculated by adding the resulting three indices together. Thus, the maximum fishery index would equal 3. This composite index assumes a linear relationship between fisheries landings and food availability to gulls, and that all three fisheries are weighted equally in terms of potential food availability; these assumptions remain untested but provide a starting point in the absence of available research.

\section{Population estimate and clutch size}

The Herring Gull population estimates were conducted on Kent Island from 13 to 15 June 2015, Hay Island on 2 June 2016, and Sheep Island on 3 June 2016. These periods coincide with optimal timing for gull census in the Gulf of Maine (Johnson and Krohn 2001) but slightly earlier than the 2001 census for Kent (21/22 June), Sheep (8 June), and Hay (26 June). This study used standardized census techniques (Walsh et al. 1995, Diamond 2000) and methods identical to the most recent ground census in 2001 (Ronconi and Wong 2001, 2003).

Kent Island was divided into five sections to estimate Herring Gull population size (Fig. 1) as per Ronconi and Wong (2001). Direct nest counts were made in section A, a 6.33-ha grassy field, and along three shoreline areas that included adjacent shrubs and ferns up to approximately $15 \mathrm{~m}$ inland from the high water line: sections C (4.90 ha), D ( 2.31 ha), and E ( 1.21 ha). The southern half of the island (section $\mathrm{B}, 31.79$ ha) contained mixed habitats 
Fig. 2. Relationships between commercial fisheries landings (a) and average Herring Gull (Larus argentatus) egg volume from Kent Island (b) between 1988 and 2015. Fisheries landings include Atlantic Herring (Clupea harengus; zone 4WX, Southwestern Nova Scotia and Bay of Fundy portion), American Lobster (Homarus americanus; Lobster Fishing Areas 35-38), and total Groundfish (cod, hake, and haddock; Atlantic Canada). Axes for tonnage of landings vary by fisheries because they are reported from raw data from different areas; they reflect regional trends in fisheries activity but do not reflect local landings around the study area. Egg measurements were obtained from collections by Environment and Climate Change Canada, which sampled 1 egg from each of 5 nests in 1988 and 1 egg from each of 15 nests every 1 to 4 years between 1992 and 2015 (Burgess et al. 2013). See methods for details on data sources.
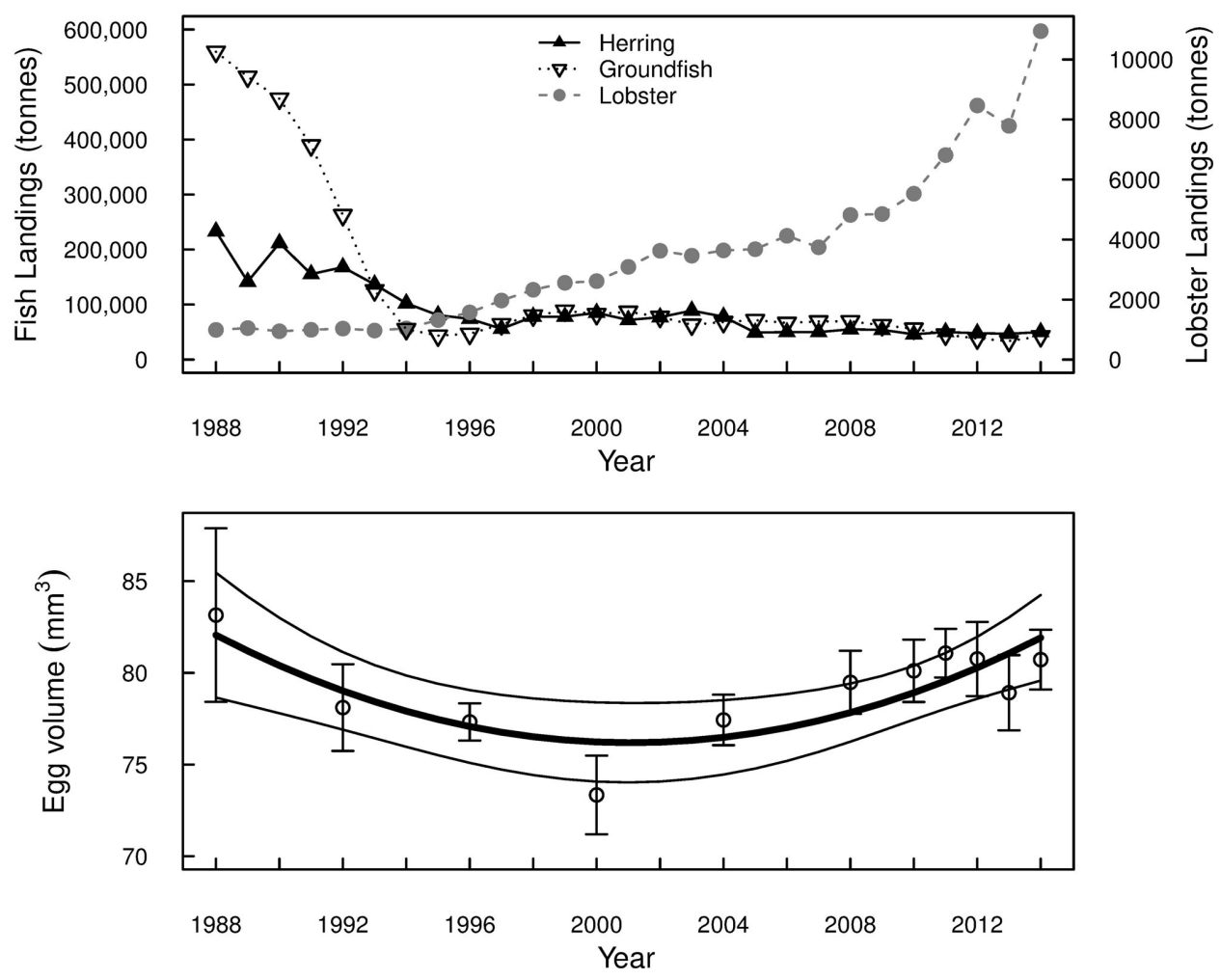

of grass, shrubs, ferns, and rocky outcrops, and was censused using ten 10-m-wide east-west transects, randomly placed along the north-south axis. Given the much smaller size, direct nest counts of the entire island were conducted on Sheep Island. Direct nest counts were also made for the entire unforested area of Hay Island (Fig. 1) because no gulls were found nesting in the forested section.

Active nests (nests containing eggs, chicks, or recently hatched) were counted, as were any nests that were capable of holding a clutch as defined by Walsh et al. (1995). The contents of each nest were recorded to determine average clutch size. Nests were marked with a small craft stick to avoid double counting and to obtain a marked vs. unmarked ratio to get a corrected estimate of initial counts. Nest counts were corrected using ratios of marked to unmarked nests, and nest densities were calculated for each of the 10 transects on Kent Island by dividing the count by the transect area.

\section{Analysis}

Mean clutch size between 2001 and 2015 on Kent Island were compared using a Student's two-tailed t-test. Trends in egg volume changes were tested with linear and quadratic regressions. To examine what environmental factors might influence egg volume, we used generalized linear models (GLM) on a set of candidate models and used Akaike Information Criterion (AIC) to select the best model. At the time of analysis, landings were not available for 2015, so only data from 1988 to 2014 were included in the models. A total of 11 candidate models were developed: (1) year, (2) herring landings, (3) lobster landings, (4) groundfish landings, (5) average May SST (SST $\left.{ }_{\text {May }}\right),(6)$ winter NAO $\left(\mathrm{NAO}_{\mathrm{W}}\right)$, (7) prey model (fishery index), (8) environmental model $\left(\mathrm{SST}_{\mathrm{May}}, \mathrm{NAO}_{\mathrm{W}}\right)$, (9) prey + environmental model (fishery index, $\mathrm{SST}_{\text {May }}, \mathrm{NAO}_{\mathrm{W}}$ ), (10) prey + year model (fishery index, year), and (11) full effects model (fishery index, year, $\mathrm{SST}_{\mathrm{May}}, \mathrm{NAO}_{\mathrm{W}}$ ). Trends in fisheries landings and SST over the study period were assessed with linear regression. All statistical analyses were run in $\mathrm{R}$ (3.3.2) using the R Stats package.

\section{RESULTS}

Average clutch size for Herring Gulls on Kent Island in 2015 was found to be $2.5(\mathrm{n}=519), 95 \% \mathrm{CI}(2.5,2.6)$ which was significantly 
Table 1. Candidate models and AIC scores testing the effects of prey availability and environmental factors on Herring Gull (Larus argentatus) egg volume on Kent Island from 1988-2014. Lobster = total lobster landings in LFA 35-38, herring = Atlantic Herring landings in 4WX, Groundfish = total groundfish landings in Atlantic Canada. Fishery Index = index encompassing lobster, herring, and groundfish landing data, sea surface temperature (SST) = average sea surface temperature in May, North Atlantic Oscillation (NAO) $=$ Winter (December-February) North Atlantic Oscillation Index, $\mathrm{K}=$ parameter count, $\mathrm{AIC}=\mathrm{Akaike}_{\text {Information }} \mathrm{Criterion} \mathrm{AIC}_{\mathrm{W}}$ $=$ Akaike Information Criterion weights.

\begin{tabular}{|c|c|c|c|c|c|c|}
\hline Model & Variables & $\mathrm{K}$ & AIC & $\Delta \mathrm{AIC}$ & $\mathrm{AIC}_{\mathrm{W}}$ & Evidence ratio \\
\hline Full effects & Fishery index, year, sst, NAO & 6 & 47.932 & 0 & 0.503 & \\
\hline Prey + year & Fishery index, year & 4 & 49.045 & 1.114 & 0.288 & 1.745 \\
\hline Prey & Fishery index & 3 & 51.483 & 3.551 & 0.085 & 5.903 \\
\hline Prey + enviro & Fishery index, sst, NAO & 5 & 52.812 & 4.880 & 0.044 & 11.475 \\
\hline Groundfish & Groundfish landings & 3 & 55.313 & 7.381 & 0.013 & 40.073 \\
\hline Lobster & Lobster landings & 3 & 55.772 & 7.840 & 0.010 & 50.412 \\
\hline Herring & Herring landings & 3 & 56.622 & 8.690 & 0.007 & 77.103 \\
\hline Year & Year & 3 & 56.856 & 8.925 & 0.006 & 86.690 \\
\hline NAO & NAO & 3 & 57.010 & 9.078 & 0.005 & 93.611 \\
\hline SST & sst & 3 & 57.049 & 9.117 & 0.005 & 95.453 \\
\hline Enviro & NAO, sst & 4 & 58.976 & 11.044 & 0.002 & 250.097 \\
\hline
\end{tabular}

greater than in $2001\left(2.3 \mathrm{t}_{1146}=1.96, \mathrm{p}<0.001\right)$. Average egg volume on Kent Island for Herring Gulls was $81.8 \mathrm{~mm}^{3}(\mathrm{n}=34)$. Across a 28 -year period, Herring Gull egg volume showed a significant quadratic relationship $\left(\mathrm{F}_{2,9}=8.894, \mathrm{R}^{2}=0.589, \mathrm{p}=0.007\right)$ with a decrease in volume from 1988 to 2000 and a subsequent increase from 2000 to 2015 (Fig. 2). Average egg volume has increased at $0.32 \mathrm{~mm}^{3}$ per year since 1996, and currently egg volume is $11.6 \%$ larger than it was at its lowest average volume, $73.3 \mathrm{~mm}^{3}$ in 2000 .

Generalized linear models assessed factors associated with variability in egg volume over a 28 year period. Fishery index, i.e., prey, was included in all three of our best candidate models, based on AIC scores, and were as follows: (1) full effects model, (2) prey + year, and (3) prey (Table 1). In all three top models, there was a significant, positive relationship between egg volume and the fishery index (Table 2; Fig. 2 showing actual fisheries landings, Fig. 3 showing predicted relationship between egg volume and fisheries index). From 1988 to 2014, there was a significant decline in herring landings $\left(\mathrm{R}^{2}=0.667, \mathrm{p}<0.001\right)$ and Atlantic groundfish landings $\left(\mathrm{R}^{2}=0.479, \mathrm{p}<0.001\right)$, and a significant increase in lobster landings $\left(\mathrm{R}^{2}=0.830, \mathrm{p}<0.001\right)$. Along with the fisheries index, spring SST and winter NAO were included in the best model (Table 1), and both showed negative correlations with egg volume, though the parameter estimates overlapped with zero, suggesting a nonsignificant effect (Table 2). Contradictory to the parameter estimate (negative association between egg size and May SST, Table 2), local spring SST have shown significant increase over the study period, particularly during the period of egg volume increase between 2000 and $2015\left(\mathrm{R}^{2}=0.30, \mathrm{p}=0.028\right.$, average increase of $0.11^{\circ} \mathrm{C} /$ year, $\min =3.4^{\circ} \mathrm{C}$ in $2004, \max =6.0^{\circ} \mathrm{C}$ in 2012).

Using counts corrected from marked:unmarked ratios (see Methods), the total estimated population size for Kent Island in 2015 was 3004 (95\% CI: 2145, 3862) Herring Gull breeding pairs (Table 3). In 2016, the total estimated population sizes for Sheep and Hay islands were 1009 and 462 breeding pairs (no confidence intervals associated with direct counts). The entire population of the Three Islands group has declined by $36 \%$ since 2001 , but proportional change varied among the islands with increases at one site (Table 3 ).
Fig. 3. Herring Gull (Larus argentatus) egg volume predicted as a function of the fishery index from the top model (Table 1). Fishery index is a relative score of combined landings of lobster, herring, and groundfish (see methods for details and caveats).

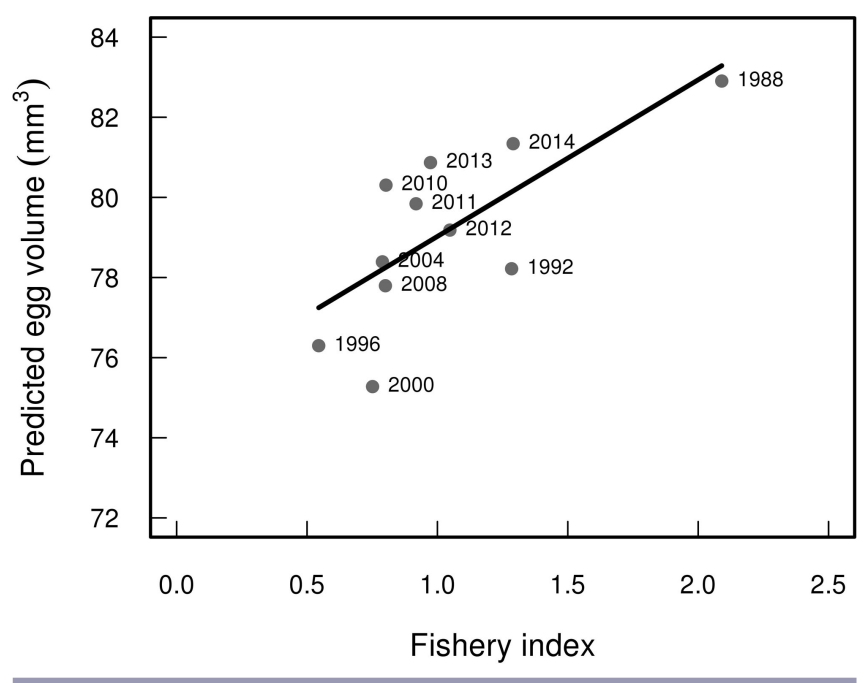

\section{DISCUSSION}

On Kent Island, Herring Gull egg volume has increased since 2000 (Fig. 2b) and average clutch size was significantly larger in $2015($ mean $=2.5)$ than in $2001($ mean $=2.3)$. Because gull egg production may be closely linked with environmental quality and resource availability (Blight 2011), these changes in reproductive variables suggest that external factor(s) may be affecting Herring Gull reproduction. Yet, the results of the population estimate indicate that the overall Herring Gull population has decreased by $36 \%$ within the Three Island Group since 2001 . 
Table 2. Parameter estimates from the top three models (Table 1) testing the effects of environmental conditions and prey availability on variability in Herring Gull (Larus argentatus) egg volume. See Table 1 and methods for full definitions of the variables.

\begin{tabular}{|c|c|c|c|c|c|}
\hline Model & Variable & Estimate & $\mathrm{p}$ & $\mathrm{SE}$ & $95 \% \mathrm{CI}$ \\
\hline \multirow{4}{*}{ Full effects } & Fishery index & 6.086 & $0.007^{*}$ & 1.496 & 3.154 to 9.017 \\
\hline & Year & 0.174 & 0.062 & 0.076 & 0.025 to 0.323 \\
\hline & sst & -0.406 & 0.544 & 0.632 & -1.645 to $0.834^{\dagger}$ \\
\hline & NAO & -0.340 & 0.135 & 0.197 & -0.725 to $0.046^{\dagger}$ \\
\hline \multirow[t]{2}{*}{ Prey + year } & Fishery index & 5.177 & $0.009^{*}$ & 1.525 & 2.187 to 8.167 \\
\hline & year & 0.140 & 0.081 & 0.070 & 0.002 to 0.278 \\
\hline Prey & Fishery index & 3.908 & 0.037 & 1.600 & 0.774 to 7.042 \\
\hline
\end{tabular}

Table 3. Estimates of Herring Gull (Larus argentatus) colony size at the Three Islands Group in the Bay of Fundy, Canada, and percentage change between 2001 and 2015/2016.

\begin{tabular}{lccc}
\hline \hline & \multicolumn{2}{c}{ Number of breeding pairs } & \\
\cline { 2 - 3 } Island & 2001 & $2015 / 2016$ & \% change \\
\hline Kent & 5926 & 3004 & -49 \\
Hay & 573 & 462 & -19 \\
Sheep & 442 & 1009 & 128 \\
Total & 6941 & 4475 & -36 \\
\hline
\end{tabular}

Breeding success and reproductive trends in colonial birds are closely associated with population size and density (Coulson et al. 1982). The increase in both egg volume and clutch size could be related to the declining breeding population over this time period. A cull of Herring Gulls between 1972-1981 in the Isle of May, Scotland produced evidence that gull population size may be inversely related to clutch and egg size (Coulson et al. 1982). As gull populations decrease, intraspecific competition is reduced, which may improve body condition in breeding adults as a result of greater access to resources, specifically food (Coulson et al. 1982). This would result in larger clutch and egg sizes in order to maximize reproductive success (Coulson et al. 1982).

Although density dependent effects may be related to the observed changes in egg volume and clutch size, the historically high and recent increase in food availability in this region (as suggested by our fishery index) is also likely a contributing factor to Herring Gull reproductive output. The quantity and quality of food availability prior to egg laying can influence the clutch and egg sizes of several seabird species (Sorensen et al. 2009, Blight 2011, Barrett et al. 2012, Kouwenberg et al. 2013). Our analyses suggest that large fluctuations in fisheries related food availability in this region has played a significant role in the changes in Herring Gull egg production (Fig. 2). Egg volume was greatest in 1988, when herring was locally abundant (DFO 2016), and prior to the collapse of Atlantic groundfish fisheries, which influenced gull populations in Atlantic Canada (Regular et al. 2013, Wilhelm et al. 2016), and changes to human waste management during the early 1990s (Chapdelaine and Rail 1997, Boyne and Beukens 2004). Groundfish landings in Atlantic Canada, and herring landings in the Bay of Fundy and southwest Nova Scotia, have remained low since 1993. Egg volume was lowest between 1992 and 2004, during this period of depressed fisheries landings in Atlantic Canada (Fig. 2a) but has been increasing in recent years following the corresponding rise in lobster landings in fishing areas around Kent Island (DFO 2013a, DFO 2015). The significant rise in SST around Kent from 2001 to 2015 may also be linked to the increase in egg volume if it has an effect on female gull diet and energy availability (Hipfner 2012), but this result had weak support in the models and the mechanism behind it is uncertain. If bait discards from lobster fisheries is an important food source supplementing the Herring Gull diet, then perhaps the effect is observed in the measured reproductive variables, due to an improved body condition in females (Coulson et al. 1982). What remains unclear however, is why there is no observed effect on the gull population size within the Three Island Group.

Notwithstanding the positive correlations between egg volume and fisheries landings, fluctuations in food availability may still be associated with the observed declining Herring Gull populations on Kent and Hay islands and the overall decline within the Three Island Group. Estimates of Herring Gull numbers on Kent Island since 1940 (Ronconi and Wong 2003) indicate that the population has declined at an average rate of 111 breeding pairs (1.33\%) per year since 1967 (a 64\% decline). In the lower Bay of Fundy, Atlantic Herring is a critical food resource for many seabirds (Diamond and Devlin 2003, Ronconi et al. 2010, Breton and Diamond 2014) and marine mammals (Overholtz and Link 2007). Herring Gull diet on Kent Island from late May to early July consists primarily of herring, mackerel, and, to a lesser extent, crab (Steenweg et al. 2011), though it is not known whether the herring in the diet comes from natural prey sources or discarded lobster bait. The decadal and seasonal variability in herring availability to gulls, whether naturally or through access via fisheries, may explain the observed population decline in Kent Island Herring Gulls despite their increased egg and clutch size in recent years. The decline in herring landings in this region since 1988 suggest that the natural herring abundance has been declining in the Bay of Fundy. In the past, the herring weir fishery in the Grand Manan Archipelago would have provided an easy means of obtaining herring from July through September, however, this fishery has also experience significant decline over the last 20 years (DFO 2015).

For birds breeding on the nearby Machias Seal Island, it has been suggested that the decline in herring availability has contributed 
to the decline in adult survival of Atlantic Puffins (Fratercula arctica; Breton and Diamond 2014) and that the quality of herring prey, e.g., energy density in the form of fat content, was also important to the breeding success of terns (Sterna spp.; Diamond and Devlin 2003). Although herring is now available to gulls as bait discards during the egg laying period, the local lobster fishing season ends on 30 June each year, thus eliminating food subsidies during much of the chick rearing period, which begins around the third week of June until chicks are fledged in August. Moreover, chick survival may also be dependent on weather conditions and depredation at the colony. Our study did not measure fledgling success or juvenile and adult survival, which may be important factors in population trajectories despite increases in egg volume at this colony.

Similar population trends have been found elsewhere in the western Atlantic, including the Bay of Fundy, Nova Scotia, and Maine (MacKinnon and Kennedy 2014, Anderson et al. 2016), and may be associated with the reduction in anthropogenic food availability, such as fishery discards (Regular et al. 2013, Wilhelm et al. 2016). However, as previously mentioned, lobster landings in the Bay of Fundy have increased considerably (DFO 2013a, DFO 2015) over this same period, leading to an increase in an alternative prey source (discarded bait from lobster traps), yet there has been no corresponding increase in Herring Gull abundance. This suggests that there are factors other than food availability affecting Herring Gull population trends in this region, which has also been proposed at other colonies, e.g. Witless Bay, Newfoundland (Bond 2016, Bond et al. 2016).

The major constraint of this study is the limited spatial and temporal snapshot of these population parameters; further studies should look at colony size and breeding biology variables on other islands in the area. A long-term monitoring study of clutch and egg size on additional islands in the Grand Manan Archipelago (and other areas in the Atlantic), as well as regular population censuses, would give us a better understanding of broad scale environmental and anthropogenic changes that may be affecting other gull populations in the Atlantic. This information is essential to further conservation efforts on these (and other) coastal avian populations in the future.

\section{AUTHOR CONTRIBUTIONS}

All authors contributed to the manuscript: Jessica Bennett and Ellen Jamieson collected the data, co-led the write-up the manuscript, and performed analyses. Robert Ronconi and Sarah Wong performed analyses, contributed to the writing, and provided feedback, comments, and advice throughout the research process.

Responses to this article can be read online at: http://www.ace-eco.org/issues/responses.php/1118

\section{Acknowledgments:}

We would like to thank J. Clarke, D. Harper, A. Hayden, A. Rehhorn, A. Stephenson, and L. Strople for their help in data collection on Kent Island, and I. Pollet for her guidance in the field. Thanks also to the 2016 Dalhousie field course students, especially B. MacGillibray, N. Pentyliuk, and C. Yamamoto who lead the Hay and Sheep Island census and I. Pratte and E. Holland for their guidance in the field. We are thankful to the staff at Bowdoin Scientific Station for logistical support on Kent Island. This is contribution number 267 from the Bowdoin Scientific Station. We also thank L. Murison and K. Ingersoll for their assistance with our field school, and N. Burgess and A. Bond for providing historical egg measurement data from Environment and Climate Change Canada. Thank you to G. Robertson for his thoughtful comments and suggestions on this manuscript, as well as the journal editors and two anonymous reviewers whose comments significantly improved this manuscript.

\section{LITERATURE CITED}

Abraham, C. L., and W. J. Sydeman. 2004. Ocean climate, euphausiids and auklet nesting: inter-annual trends and variation in phenology, diet and growth of planktivorous seabird, Ptychoramphus aleuticus. Marine Ecology Progress Series 274:235-250. http://dx.doi.org/10.3354/meps274235

Anderson, J. G. T., K. R. Shlepr, A. L. Bond, and R. Ronconi. 2016. Introduction: a historical perspective on trends in some gulls in eastern North America, with reference to other regions. Waterbirds 39(sp1):1-9. http://dx.doi.org/10.1675/063.039.sp106

Barber, R. T., and F. P. Chavez. 1983. Biological consequences of El Niño. Science 222:1203-1210. http://dx.doi.org/10.1126/ science.222.4629.1203

Barrett, R. T., E. B. Nilsen, and T. Anker-Nilssen. 2012. Longterm decline in egg size of Atlantic Puffins Fratercula arctica is related to changes in forage fish stocks and climate conditions. Marine Ecology Progress Series 457:1-10. http://dx.doi. org/10.3354/meps09813

Blight, L. K. 2011. Egg production in a coastal seabird, the Glaucous-winged Gull (Larus glaucescens), declines during the last century. PLoS ONE 6(7):e22027. http://dx.doi.org/10.1371/ journal.pone.0022027

Bond, A. L. 2016. Diet changes in breeding herring gulls (Larus argentatus) in Witless Bay, Newfoundland and Labrador, Canada over 40 years. Waterbirds 39:152-158. http://dx.doi.org/10.1675/063.039. sp115

Bond, A. L., S. I. Wilhelm, G. J. Robertson, and S. Avery-Gomm. 2016. Differential declines among nesting habitats of breeding Herring Gulls (Larus argentatus) and Great Black-backed Gulls (Larus marinus) in Witless Bay, Newfoundland and Labrador, Canada. Waterbirds 39:143-151. http://dx.doi.org/10.1675/063.039. sp105

Boyne, A. W., and J. T. Beukens. 2004. Census of gulls and other seabirds along the coast of mainland Nova Scotia - 2002. Technical Report Series No. 409. Canadian Wildlife Service, Atlantic Region, Sackville, New Brunswick, Canada.

Breton, A. R., and A. W. Diamond. 2014. Annual survival of adult Atlantic Puffins Fratercula arctica is positively correlated with Herring Clupea harengus availability. Ibis 156:35-47. http:// dx.doi.org/10.1111/ibi.12100

Burgess, N. M., A. L. Bond, C. E. Hebert, E. Neugebauer, and L. Champoux. 2013. Mercury trends in Herring Gull (Larus argentatus) eggs from Atlantic Canada, 1972-2008: temporal 
change or dietary shift? Environmental Pollution 172:216-222. http://dx.doi.org/10.1016/j.envpol.2012.09.001

Cairns, D. K. 1987. Seabirds as indicators of marine food supplies. Biological Oceanography 5:261-271.

Chapdelaine, G., and J.-F. Rail. 1997. Relationship between cod fishery activities and the population of Herring Gulls on the North Shore of the Gulf of St Lawrence, Québec, Canada. ICES Journal of Marine Science 54:708-713. http://dx.doi.org/10.1006/ jmsc. 1997.0248

Clifford, L. D., and D. J. Anderson. 2001. Food limitation explains most clutch size variation in the Nazca Booby. Journal of Animal Ecology 70(4):539-545. http://dx.doi.org/10.1046/j.1365-2656.2001.00521. $\mathrm{x}$

Conversi, A., S. Piontkovski, and S. Hameed. 2001. Seasonal and interannual dynamics of Calanus finmarchicus in the Gulf of Maine (Northeastern US shelf) with reference to the North Atlantic Oscillation. Deep-Sea Research Part II 48(1-3):519-530. http://dx.doi.org/10.1016/S0967-0645(00)00088-6

Coulson, J. C., N. Duncan, and C. Thomas. 1982. Changes in the breeding biology of the Herring Gull (Larus argentatus) induced by reduction in the size and density of the colony. Journal of Animal Ecology 51:736-756. http://dx.doi.org/10.2307/4002

Cury, P. M., I. L. Boyd, S. Bonhommeau, T. Anker-Nilssen, R. J. M. Crawford, R. W. Furness, J. A. Mills, E. J. Murphy, H. Österblom, M. Paleczny, J. F. Piatt, J.-P. Roux, L. Shannon, and W. J. Sydeman. 2011. Global seabird response to forage fish depletion - one-third for the birds. Science 334(6063):1703-1706. http://dx.doi.org/10.1126/science.1212928

Department of Fisheries and Oceans Canada. 2013a. Assessment of lobster (Homarus americanus) in Lobster Fishing Areas (LFA) 35-38. DFO Canadian Science Advisory Secretariat Science Advisory Report 2013/023. DFO, Ottawa, Ontario, Canada. [online] URL: http://waves-vagues.dfo-mpo.gc.ca/Library/348828. pdf

Department of Fisheries and Oceans Canada. $2013 b$. Hydrographic data. DFO, Ottawa, Ontario, Canada. [online] URL: http://www.meds-sdmm.dfo-mpo.gc.ca/isdm-gdsi/azmppmza/hydro/index-eng.html

Department of Fisheries and Oceans Canada. 2015. 2015 Stock status update of lobster (Homarus americanus) in the Bay of Fundy (Lobster Fishing Areas 35-38). DFO Canadian Science Advisory Secretariat Science Response. 2015/030. DFO, Ottawa, Ontario, Canada. [online] URL: http://publications.gc.ca/collections/ collection_2016/mpo-dfo/Fs70-7-2015-030-eng.pdf

Department of Fisheries and Oceans Canada. 2016. 4VWX Herring 2016 update report. DFO Canadian Science Advisory Secretariat Science Advisory Report 2016/036. DFO, Ottawa, Ontario, Canada. [online] URL: http://www.dfo-mpo.gc.ca/csassccs/Publications/ScR-RS/2016/2016_036-eng.pdf

Diamond, A. W. 2000. Marine biodiversity monitoring: protocol for monitoring seabirds. University of New Brunswick, Fredericton, New Brunswick, Canada. [online] URL: http://www. unb.ca/research/alar/_resources/pdf/publications/eman-seabirdmonitoring-protocol-2001.pdf
Diamond, A. W., and C. M. Devlin. 2003. Seabirds as indicators of changes in marine ecosystems: ecological monitoring on Machias Seal Island. Environmental Monitoring and Assessment 88(1):153-181. http://dx.doi.org/10.1023/A:1025560805788

Farmer, R. G., and M. L. Leonard. 2011. Long-term feeding ecology of great Black-backed Gulls (Larus marinus) in the northwest Atlantic: 110 years of feather isotope data. Canadian Journal of Zoology 89:123-133. http://dx.doi.org/10.1139/ Z10-102

Food and Agriculture Organization of the United Nations. 2016. Fishery statistical collections: global production. Fisheries and Aquaculture Department, FAO, Rome, Italy. [online] URL: http://www.fao.org/fishery/statistics/global-production/en

Furness, R. W., and K. C. J. Camphuysen. 1997. Seabirds as monitors of the marine environment. ICES Journal of Marine Sciences 54:726-737. http://dx.doi.org/10.1006/jmsc.1997.0243

Gremillet, D., and T. Boulinier. 2009. Spatial ecology and conservation of seabirds facing global climate change: a review. Marine Ecology Progress Series 391:121-137. http://dx.doi. org/10.3354/meps08212

Harris, M. P. 1964. Aspects of the breeding biology of the gulls Larus argentatus, L. fuscus and L. marinus. Ibis 106:432-456. http://dx.doi.org/10.1111/j.1474-919X.1964.tb03725.x

Hipfner, J. M. 2012. Effects of sea-surface temperature on egg size and clutch size in the Glaucous-winged Gull. Waterbirds 35 (3):430-436. http://dx.doi.org/10.1675/063.035.0307

Hurrell, J. W., and C. Deser. 2009. North Atlantic climate variability: the role of the North Atlantic Oscillation. Journal of Marine Systems 78(1):28-41. http://dx.doi.org/10.1016/j.

jmarsys.2008.11.026

Johnson, C. M., and W. B. Krohn. 2001. The importance of survey timing in monitoring breeding seabird numbers. Waterbirds 24 (1):22-33. http://dx.doi.org/10.2307/1522239

Kouwenberg, A. L., J. M. Hipfner, D. W. McKay, and A. E. Storey. 2013. Corticosterone and stable isotopes in feathers predict egg size in Atlantic Puffins Fratercula arctica 155(2):413-418.

MacInnes, C. D., and E. H. Dunn. 1988. Estimating proportion of an age class nesting in Canada Geese. Journal of Wildlife Management 52:421-423. http://dx.doi.org/10.2307/3801583

MacKinnon, C. M., and A. C. Kennedy. 2014. Decline in breeding of the Great Black-backed Gull, Larus marinus and the Herring Gull, L. argentatus, on Boot Island, Nova Scotia, 1986 to 2010. Canadian Field-Naturalist 128(2):165-172. http://dx.doi.org/10.22621/ cfn.v128i2.1581

Mallory, M. L., S. A. Robinson, C. E. Herbert, and M. R. Forbes. 2010. Seabirds as indicators of aquatic ecosystem conditions: a case for gathering multiple proxies of seabird health. Marine Pollution Bulletin 60:7-12. http://dx.doi.org/10.1016/j. marpolbul.2009.08.024

National Center for Atmospheric Research (NCAR). 2015. Climate Data. Hurrell North Atlantic Oscillation (NAO) Index (Station-based). NCAR, Boulder, Colorado, USA. [online] URL: https://climatedataguide.ucar.edu/climate-data/hurrell-northatlantic-oscillation-nao-index-station-based 
Niizuma, Y., M. Takagi, M. Senda, M. Chochi, and Y. Watanuki. 2005. Incubation capacity limits maximum clutch size in Blacktailed Gulls Larus crassirostris. Journal of Avian Biology 36:421-427. http://dx.doi.org/10.1111/j.0908-8857.2005.03252.x

Overholtz, W. J., and J. S. Link. 2007. Consumption impacts by marine mammals, fish, and seabirds on the Gulf of MaineGeorges Bank Atlantic herring (Clupea harengus) complex during the years 1977-2002. ICES Journal of Marine Science 64 (1):83-96.

Parsons, J. 1975. Seasonal variation in the breeding success of the Herring Gull: an experimental approach to pre-fledging success. Journal of Animal Ecology 44(2):553-573. http://dx.doi. org/10.2307/3611

Piatt, J. F., A. M. A. Harding, M. Shultz, S. G. Speckman, T. I. Van Pelt, G. S. Drew, and A. B. Kettle. 2007. Seabirds as indicators of marine food supplies: Cairns revisited. Marine Ecology Progress Series 352:221-234. http://dx.doi.org/10.3354/meps07078

Pierotti, R. J., and T. P. Good. 1994. Herring Gull (Larus argentatus). In A. Poole, editor. The Birds of North America online. Cornell Lab of Ornithology, Ithaca, New York, USA. https://doi. org/10.2173/bna.hergul.03

Pons, J. M. 1992. Effects of changes in the availability of human refuse on breeding parameters in a Herring Gull Larus argentatus population in Brittany, France. Ardea 80(1):143-150.

Regular, P., W. Montevecchi, A. Hedd, G. Robertson, and S. Wilhelm. 2013. Canadian fishery closures provide a large-scale test of the impact of gillnet bycatch on seabird populations. Royal Society Publishing: Biology Letters 9(4):20130088. http://dx.doi. org/10.1098/rsbl.2013.0088

Ronconi, R. A., H. N. Koopman, C. A. E. McKinstry, S. N. P. Wong, and A. J. Westgate. 2010. Inter-annual variability in diet of non-breeding pelagic seabirds Puffinus spp. at migratory staging areas: evidence from stable isotopes and fatty acids. Marine Ecology Progress Series 419:267-282. http://dx.doi. org/10.3354/meps08860

Ronconi, R. A., and S. N. P. Wong. 2001. Seabird colonies of the Grand Manan Archipelago: 2001 census results and guidelines for surveys and future monitoring. Bulletin No. 4. Grand Manan Whale and Seabird Research Station, Grand Manan, New Brunswick, Canada.

Ronconi, R. A., and S. N. P. Wong. 2003. Estimates of changes in seabird numbers in the Grand Manan Archipelago, New Brunswick, Canada. Waterbirds 26:462-472. http://dx.doi. org/10.1675/1524-4695(2003)026[0462:EOCISN]2.0.CO;2

Sorensen, M. C., M. J. Hipfner, K. T. Kyser, and R. D. Norris. 2009. Carry-over effects in a Pacific seabird: stable isotope evidence that pre-breeding diet quality influences reproductive success. Journal of Animal Ecology 78(2):460-467. http://dx.doi. org/10.1111/j.1365-2656.2008.01492.x
Steenweg, R. J., R. A. Ronconi, and M. L. Leonard. 2011. Seasonal and age-dependent dietary partitioning between the Great Black-backed and Herring gulls. Condor 113(4):795-805. http://dx.doi.org/10.1525/cond.2011.110004

Walsh, P. M., D. J. Halley, M. P. Harris, A. del Nevo, L. M. W. Sim, and M. L. Tasker. 1995. Seabird monitoring handbook for Britain and Ireland: a compilation of methods for survey and monitoring of breeding seabirds. Joint Nature Conservation Committee, Royal Society for the Protection of Birds, Institute of Terrestrial Ecology, and Seabird Group, Peterborough, UK.

Wanless, S., M. P. Harris, P. Redman, and J. R. Speakman. 2005. Low energy values of fish as a probable cause of a major seabird breeding failure in the North Sea. Marine Ecology Progress Series 294:1-8. http://dx.doi.org/10.3354/meps294001

Wilhelm, S. I., J.-F. Rail, P. M. Regular, C. Gjerdrum, and G. J. Robertson. 2016. Large-scale changes in abundance of breeding Herring Gulls (Larus argentatus) and Great Black-backed Gulls (Larus marinus) relative to reduced fishing activities in southeastern Canada. Waterbirds 39(sp1):136-142. http://dx.doi. org/10.1675/063.039.sp104
Editor-in-Chief: Ryan Norris

Subject Editor: Alexander L.Bond
Sponsored by the Society of Canadian Ornithologists and Bird Studies Canada Parrainée par la Société des ornithologistes du Canada et Études d'oiseaux Canada

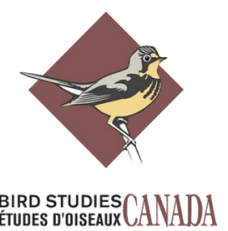

